\title{
Sistem Religi Dan Kepercayaan Masyarakat Kasepuhan Sinar Resmi Cisolok Sukabumi
}

\author{
Suidat $^{1}$, Diah Winarsih ${ }^{1}$, Ahmad Rojali Said ${ }^{1}$ (12pt) \\ ${ }^{1}$ Program, Magister PPKn STKIP Arrahmaniyah Depok, Indonesia
}

\begin{abstract}
Abstrak-Tujuan dari kajian ini adalah mengidentifkasi sistem religi dan kepercayaan pada masyarakat Kasepuhan Sinar Resmi. Suatu sistem religi dalam suatu kebudayaan selalu mempunyai ciri-ciri untuk sedapat mungkin memelihara emosi keagamaan itu diantara pengikut-pengikutnya. Dengan demikian emosi keagamaan merupakan unsur penting dalam suatu religi bersama dengan tiga unsur lain,yaitu; sistem keyakinan; sistem upacara keagamaan; umat yang menganut religi. Sistem upacara keagaman secara khusus mengandung emosi aspek yang menjadi perhatian khusus adalah: Tempat upacara keagamaan dilakukan; Saat-saat upacara keagamaan dijalankan; Benda-benda dan alatalat upacara; Orang-orang yang melakukan dan memimpin upacara. Warga Kasepuhan mempunyai keyakinan bahwa seseorang yang ingin sukses hidupnya atau bahagia, ia harus dapat mencapai satu kesatuan hidup atau rasa manunggal, yakni menyatukan alam makro kosmos dengan mikro kosmos. Sebuah ungkapan yang sering dijadikan pedoman untuk mencapai rasa yang dimaksud adalah tilu sapamilu, dua sakarupa, hiji eta keneh (tiga sejenis, dua serupa, satu itu-itu juga),tata nilai ini mengandung pengertian bahwa hanya dapat dilakukan dengan tiga syarat, yaitu 1) tekad, ucap dan lampah (niat, pemikiran dan tindakan) harus selaras dan dapat dipertanggungjawabkan kepada incu-putu (keturunan masyarakat kasepuhan) dan sesepuh (orang tua dan nenek moyang). 2) jiwa, raga dan perilaku harus selaras dan berakhlak. 3) kepercayaan adat sara, nagara dan mokaha harus selaras, harmonis dan tidak bertentangan satu dengan
\end{abstract}

Kata kunci: Sistem Religi, Sistem Kepercayaan, Kasepuhan Sinar Resmi

\section{Histori:}

Dikirim: 20 Agustus 2021

Direvisi: 29 September 2021

Diterima: 30 September 2021

Online: 30 September 2021 lainnya.

\section{Identitas Artikel:}

Suidat, S., Winarsih, D., \& Said, A.R. (2021). Sistem Religi Dan Kepercayaan Masyarakat Kasepuhan Sinar Resmi Cisolok Sukabumi. Jurnal Citizenship Virtues, 1(2), 113-123.

\section{PENDAHULUAN}

Kasepuhan Sinar Resmi, merupakan salah satu masyarakat adat yang tinggal di kawasan Taman Nasional Gunung Halimun Salak (TNGHS), Jawa Barat. Tatali paranti karuhun menjadi dasar budaya masyarakat kasepuhan untuk tetap memper-tahankan kearifan lokal sebagai implementasi flosof hidupnya dalam bentuk religi, pandangan hidup, mata pencaharian dan aktivitas sosial budaya

\footnotetext{
$1_{*}$ Corresponding author.

E-mail: jaliksaid@gmail.com
} 
yang berjalan dari generasi satu ke generasi selanjutnya. Filosof hidup masyarakat Kasepuhan Sinar Resmi adalah sebagai Pancer pangawinan, yaitu mempersatukan manusa jeung kemanusaanna(manusia dengan kemanusiaannya), dan menjadi dasar dalam tindakan sehari-hari yang disebut ngaji diri (mawas diri) atau memahami diri sendiri. Bersikap mawas diri artinya selalu berhati-hati dalam bersi-kap dan berbicara terhadap sesama manusia. Ngaji diri menjadi pilar kehidupan masyarakat dalam membina hubungan antar sesama masyarakat kasepuhan, yakni dalam tekad, ucap jeung lampah (kemauan/ niat, perkataan dan perilaku). Niat merupakan titik awal dalam melakukan sesuatu yang tercermin dalam perkataan dan perilaku seseorang, sehingga ketidaksesuaian antar ketiganya menimbulkan perilaku munafk. Dalam berucap harus selalu sopan dan berhatihati, 'saur kedah diukur, nyabda kedah diuger' agar tidak menimbulkan salah paham dan menyinggung perasaan orang lain.

Batas pada permukiman kasepuhan terbagi menjadi dua, yakni batas fsik dan batas non fsik. Batas fsik pada permukiman kasepuhan Sinar Resmi berupa sungai, hutan, sawah kebun, bukit, talun, maupun pagar bambu. Sedangkan yang menjadi batas non fsik berhubungan dengan kepercayaan warga terhadap hal-hal yang tidak kasat mata. Batas non fsik sulit untuk dibuktikan, karena berkaitan dengan keyakinan warga, tetapi dapat dirasakan seperti: takut, angker, menyeramkan dan lain-lain. Tempat-tempat yang jarang atau tidak pernah dimasuki oleh manusia dipercaya memiliki kekuatan jahat, seperti leuweung tutupan, makam dan pohon besar. Kepercayaan warga terhadap roh-roh halus, secara tidak langsung menjadi batas permukiman dan merupakan bukti pengakuan mereka akan eksistensi serta hubungan erat antara yang kasat mata dengan yang tidak kasat mata. Hubungan tersebut terlihat pada pelaksanaan berbagai upacara ritual dan pemberian sesajen dengan tujuan untuk menghormati atau mengharap berkah. Menurut Adimihardja, hal tersebut meru-pakan ciri masyarakat tradisional yang masih mem-percayai larangan, seperti adanya makhluk-makhluk atau wujud-wujud yang sakral, bersifat gaib, tidak dapat dibuktikan secara eksperimental tentang keberadaannya, karena bagi yang tidak tahu dan tidak percaya menganggap hal itu tidak ada. Namun bagi yang mempercayainya perasaan ka-gum dan tunduk pada objek-objek yang disakralkan tetap menjadi landasan hubungan dengan yang disakralkan.

Pola linier terdapat pada bangunan yang berhadapan dengan jalan, sedangkan untuk bangunan-bangunan yang terdapat di belakang rumah tersebut tata massanya mengikuti kontur lahan sehingga terkesan tidak beraturan. Bangunan-bangunan yang berhadapan dengan jalan ditata secara linier mengikuti alur jalan pada kampung. Sedangkan bangunan-bangunan di belakangnya, bumi warga dikenal dengan sebutan daerah hilir, karena posisinya di bawah girang. Pembagian girang dan hilir didasarkan pada dua alasan, pertama: girang merupakan tempat kedudukan (tempat tinggal) pimpinan adat yang harus dihormati, sedangkan hilir merupakan tempat kedudukan warga kasepuhan yang harus tunduk dan patuh pada pimpinannya. Kedua, berdasarkan pada kontur tanah yang tidak rata.

Pada tata ruang secara makro dan meso, bumi ageung harus diletakkan pada sumbu utara-selatan, atau bagian depannya menghadap ke selatan. Dalam pandangan warga, selatan atau kidul dipercaya sebagai tempat ngancikna atau bersema-yamnya Nyi Sri Pohaci (Dewi Padi) yang setiap saat 'memberikan' 
kesuburan pangan bagi warga kasepuhan. Arah selatan juga memiliki makna kaindung (ibu) sedangkan utara ka bapa (bapak). Hal ini merupakan perwujudan makna bahwa setiap anak harus menghormati kedua orang tuanya sesuai peribahasa: "indung tunggulna rahayu, bapa tangkalna darajat", artinya ibu sumber kesejahteraan dan bapak sumber keselamatan.

Secara makro, makam berada di tempat yang tinggi berdekatan dengan hutan, dengan orientasi barat-timur. Hal ini berkaitan dengan pandangan masyarakat kasepuhan, barat sebagai simbol kabinasaan (kematian) dan timur sebagai simbol kahirupan (kehidupan). Barat atau kulon merupakan tempat surupna panon poe atau batara surya (terbe-namnya matahari), sedangkan timur atau wetan merupakan tempat bijilna panon poe (terbitnya matahari). Secara makro, terbentuk ruang sakral dan profan pada kampung kasepuhan Sinar Resmi. Hutan dan makam merupakan ruang sakral, se-dangkan permukiman merupakan ruang profan. Posisi ketinggian menjadi batas secara fsik antara ruang sakral dengan profan, dan kepercayaan dan kepatuhan warga terhadap larangan untuk me-masuki hutan menjadai batas non fsik. Makam menjadi area yang sakral karena sebelum memulai sebuah ritual tradisi, misalnya seren taun. Warga mendatangi makam leluhur untuk memohon restu agar apa yang diharapkan dapat berjalan lancar sesuai harapan.

Semua masyarakat di kampung adat Kasepuhan memeluk agama Islam. Namun dalam kehidupan sehari-hari pelaksanaan kegiatan keagamaannya masih didominasi kepercayaan terhadap adat tradisi nenek moyangnya (tatali paranti karuhun). Kepercayaan leluhur dan agama Islam berjalan beriringan. Keduanya sama-sama memerintahkan pada kebaikan dan melarang pada kejahatan. Walaupun semua masyarakat beragama Islam, tapi mereka masih mempertahankan kepercayaaan leluhur seperti membakar menyan, memberikan sesajen, upacara-upacara adat, memasang tolak bala di pintu, dan kepercayaan leluhur lainnya. Di Kasepuhan Ciptamulya dan Sinar Resmi terdapat satu Masjid Jami' yang digunakan untuk berjamaah dan digunakan untuk pengajian rutinan. Berdasarkan hasil wawancara dengan Penghulu (ustadz) di Kesepuhan Ciptamulya diterangkan bahwasannya masyarakat Ciptamulya sangat antusias dalam hal keagamaan baik dalam hal pengajian dan lain sebagainya, hal tersebut menurut Bapak Ade terbukti dengan banyaknya ibu-ibu masyarakat adat Kasepuhan yang mengikuti pengajian rutinan setiap Jumat sore. Demikian pula adanya PAUD sebagai sarana mengaji anak-anak. Kegiatan keagamaan lainnya sama halnya dengan masyarakat Islam disekitar yakni Tahlil (jika ada yang meninggal) dan memperingati hari-hari besar Islam seperti : Rajaban, Muludan, dan lain sebagainya, bahkan dalam kegiatan-kegiatan tersebut mereka mengundang mubaligh atau ustadz untuk ceramah. Atas dasar permasalahan tersebut, maka ingin lebih dalam dikaji terkait sistem religi dan kepercayaan pada masyarakat Kasepuhan Sinar Resmi.

\section{METODE PENELITIAN}

Kajian dilakukan dengan analisa secara deskriptif kualitatif untuk mengkaji dan mengidentifikasi sistem religi dan kepercayaan pada masyarakat Kasepuhan Sinar Resmi. Data sekunder diperoleh melalui literasi pustaka maupun wawancara mengenai sistem religi dan kepercayaan pada masyarakat Kasepuhan 
Sinar Resmi. Metode penelitian deskriptif kualitatif yaitu suatu penelitian yang menekankan pada proses dan mengutamakan makna. (Pudjiastuti;2019). Tujuan penelitian kualitatif adalah ingin memperoleh pemahaman makna, menggambarkan realitas yang kompleks karena ingin mengkaji dan menganalisis sistem religi dan kepercayaan pada masyarakat Kasepuhan Sinar Resmi. Objek dalam penelitian ini adalah masyarakat adat kasepuhan yang berlokasi di Sinar Resmi, Cisolok, Sukabumi. Informan dalam peneltian ini adalah ketua adat, anggota biasa, Tokoh masyarakat formal, Tokoh adat. Di dalam penelitian ini, sumber data yang digunakan adalah Sumber Data Primer yaitu data yang diperoleh secara langsung dari informan penelitian di kasepuhan Sinar Resmi melalui wawancara mendalam (in-depth interview), observasi terutama tentang sistem religi dan kepercayaan pada masyarakat Kasepuhan Sinar Resmi. Teknik pengumpulan data yang digunakan adalah Wawancara Mendalam (In-depth Intreview) kepada para informan sehingga tergali sistem religi dan kepercayaan pada masyarakat Kasepuhan Sinar Resmi. Studi Dokumentasi yaitu peneliti membaca dokumen yang berhubungan dengan sistem religi dan kepercayaan pada masyarakat Kasepuhan Sinar Resmi. Observasi yaitu memahami apa yang terjadi pada kasepuhan ini dengan menggunakan seluruh indra peneliti, misalnya dengam melihat lingkungan setempat atau peneliti menggunakan kamera sehingga penelitian ini absah Prosedur pengumpulan data yang dilakukan pada penelitian ini adalah 1) Mengujungi lokasi penelitian yaitu Kasepuhan Sinar Resmi dan menemui informan yang telah ditentukan yang menjadi subjek penelitian, 2) Melakukan wawancara.

\section{HASIL DAN PEMBAHASAN}

Kasepuhan Banten Kidul adalah kelompok masyarakat adat Sunda yang tinggal di sekitar Gunung Halimun, terutama di wilayah Kabupaten Sukabumi sebelah barat hingga ke Kabupaten Lebak, dan ke utara hingga ke Kabupaten Bogor. Kasepuhan (sepuh; tua) menunjuk pada adat istiadat lama yang masihdipertahankan dalam kehidupan sehari hari. Masyarakat Kasepuhan Banten Kidul sekarang, melingkup beberapa desa tradisional dan setengah tradisional, yang masih mengakui kepemimpinan adat setempat. Terdapat beberapa Kasepuhan di antaranya adalah Kasepuhan Sinar Resmi, Kasepuhan Cipta Mulya. Kasepuhan Ciptagelar, Kasepuhan Cisungsang, Kasepuhan Cisitu, Kasepuhan Cicarucub, Kasepuhan Citorek, serta Kasepuhan Cibedug. Kampung adat Kasepuhan adalah sekelompok masyarakat adat yang memegang teguh dalam istilah Sunda disebut "anu nyepeng tetekon adat tradisi" para leluhur, dan salah satu ritual adat tahunan Kasepuhan yang selalu menarik minat masyarakat adalah upacara Seren Taun; yang sesungguhnya adalah pernyataan syukur warga Kasepuhan atas keberhasilan panen padi, artinya semua pelaksanan ritual dan kepercayaan di kesatuan adat Kasepuhan Banten Kidul ini adalah sama, baik dalam kepecayaan, ritual bacaan doa maupun pelaksanaanya. Pada tulisan ini, penulis hanya membahas objek 3 (tiga) kasepuhan saja, yakni: Kasepuhan Ciptamulya, Kasepuhan Sinar Resmi dan Kasepuhan Ciptagelar. Hal tersebut mengingat ketiga kasepuhan ini merupakan kasepuhan inti dari Kesatuan Adat Kasepuhan Banten Kidul yang terletak di desa Sirna Resmi Kecamatan Cisolok Kabupaten Sukabumi. 
Sistem Religi di Kasepuhan Adat Sinar Resmi

Koentjaraningrat (bapak antropologi Indonesia) mendefinisikan religi yang memuat hal-hal tentang keyakinan, upacara dan peralatannya, sikap dan perilaku,alam fikiran dan perasaan disamping hal-hal yang menyangkut para penganutnya sendiri. Suatu sistem religi dalam suatu kebudayaan selalu mempunyai ciri-ciri untuk sedapat mungkin memelihara emosi keagamaan itu diantara pengikutpengikutnya. Dengan demikian emosi keagamaan merupakan unsur penting dalam suatu religi bersama dengan tiga unsur lain, yaitu (i) sistem keyakinan; (ii) sistem upacara keagamaan; (iii) suatu umat yang menganut religi itu ( Koentjaraningrat, 2015).

Dalam membahas pokok antropologi tentang religi, sebaiknya juga dibicarakan system ilmu gaib sehingga pokok itu dapat dibagi menjadi dua pokok khusus yaitu(1) sistem religi dan (2) sistem ilmu gaib. Semua aktivitas manusia yang bersangkutan dengan religi berdasarkan atas suatu getaran jiwa, yang biasanya disebut emosi keagamaan (religious emotion).(Piotr;2011) Emosi keagamaan ini biasanya pernah dialami oleh setiap manusia, walaupun getaran emosi itu mungkin halnya berlangsung untuk beberapa detik saja, untuk kemudian menghilang lagi. Emosi keagamaan itulah yang mendorong orang melakukan tindakan-tindakan bersifat religi.

Diantara subunsur religi adalah mengenai umat yang menganut agama atau religi yang bersangkutan. Secara khusus subunsur itu meliputi masalah pengikut suatu agama, hubungan antara satu dengan yang lainnya, hubungan dengan para pemimpin agama, baik dalam saat adanya upacara keagamaan maupun kehidupan sehari-hari; dan akhirnya subunsur itu juga meliputi masalah seperti organisasi dari para umat, kewajiban, serta hak-hak para warganya ( Suwandi;2009).

Menurut pandangan psikodinamik, perilaku manusia dipengaruhi oleh faktor internal. Yaitu bagaimana perilaku dipengaruhi oleh konflik yang ada dalam diri manusia, motivasi dan pertahanan psikologis yang dikembangkan untuk mengatasinya. Pikiran merupakan alat untuk menangani kekuatan konflik tersebut dan perilaku aktual menunjukkan kesesuaian antara kekuatan tersebut.(Pudjiastuti;2020). Mery Evlyn Tucker (2003: 85) mengatakan bahwa "agama memiliki lima resep dasar: (1) referensi atau keyakinan yang dapat diperoleh dari teks-teks (kitab suci) dan kepercayaan yang umat manusia yakini. (2) respek, penghargaan kepada semua makhluk hidup yang diajarkan oleh agama sebagai makhluk Tuhan. (3) restain, kemampuan untuk mengelola dan mengontrol sesuatu supaya penggunaannya tidak mubazir. (4)redistribustion, kemampuan untuk menyebarkan kekayaan, kegembiraan, dan kebersamaan melalui langkah dermawan, misalnya zakat dan Infak. (5)responsibility, sikap bertanggung jawab dalam merawat kondisi lingkungan dan alam sekitar.

Pendapat tersebut sudah sejalan dengan sistem religi di kasepuhan Sinar Resmi. Oleh karena itu melalui system religi ini diharapkan selain dapat menggugah kesadaran umat Islam untuk lebih memahami dan peduli terhadap kondisi lingkungannya, dan juga diharapkan dapat melakukan penggalian dan pengkajian secara komprehensif tentang konsep Islam yang berkaitan dengan lingkungan serta implementasinya. Dengan bentuk ikhtiar ini akan menjadikan 
kasepuhan Sinar Resmi sebagai pusat pembelajaran lingkungan bagi masyarakat.(Pudjiastuti; 2021).

Warga Kasepuhan merupakan masyarakat adat yang masih teguh memegang dan menjalankan tradisi leluhur dengan pengawasan abah sebagai tutunggul kasepuhan. Penduduk warga Kasepuhan merupakan pemeluk agama Islam yang taat, akan tetapi dalam kehidupan sehariharinya diwarnai oleh kepercayaan-kepercayaan bersifat mitos dan animisme, mereka masih mempertahankan kepercayaaan leluhur seperti membakar menyan, memberikan sesajen, upacara-upacara adat, memasang tolak bala di pintu, dan kepercayaan leluhur lainnya(tatali paranti karuhun).Hal tersebut dapat terlihat dari kehidupan mesyarakatya sehari-hari dalam memegang tradisi ada (tetekon) terutama dalam hal bercocok tanaman yang tidak lepas dari aturan (tetekon) yang telah ditentukan oleh pemangku adat.

Warga Kasepuhan mempunyai keyakinan bahwa seseorang yang ingin sukses hidupnya atau bahagia, ia harus dapat mencapai satu kesatuan hidup atau rasa manunggal, yakni menyatukan alam makro kosmos dengan mikro kosmos. Sebuah ungkapan yang sering dijadikan pedoman untuk mencapai rasa yang dimaksud adalah tilu sapamilu, dua sakarupa, hiji eta keneh (tiga sejenis, dua serupa, satu itu-itu juga),tata nilai ini mengandung pengertian bahwa hanya dapat dilakukan dengan tiga syarat, yaitu 1) tekad, ucap dan lampah (niat, pemikiran dan tindakan) harus selaras dan dapat dipertanggungjawabkan kepada incu-putu (keturunan masyarakat kasepuhan) dan sesepuh (orang tua dan nenek moyang). 2) jiwa, raga dan perilaku harus selaras dan berakhlak. 3) kepercayaan adat sara, nagara dan mokaha harus selaras, harmonis dan tidak bertentangan satu dengan lainnya.

Sistem kepercayaan/ kayakinan secara khusus mengandung banyak subunsur lagi. Dalam rangka ini para ahli antroplogi biasanya menaruh perhatian terhadap konsepsi tentang dewa-dewa yang baik maupun yang jahat; sifat-sifat dan tanda-tanda dewa-dewa; konsepsi tentang mahluk-mahluk halus lainya seperti roh-roh leluhur, roh-roh lain yang baik maupuan yang jahat, hantu dan lain-lain; konsepsi tentang dewa tertinggi dan pencipta alam; masalah terciptanya dunia dan alam (kosmologi); masalah mengenai bentuk dan sifat-sifat dunia dan alam (kosmologi); konsepsi tentang hidup dan mati konsepsi tentang dunia roh dan dunia akhirat lainlain ( Toto Sucipto, 2008). Adapun sistem kepercayaan dan gagasan, pelajaran aturan agama, dongeng suci tentang riwayat-riwayat dewadewa (mitologi), biasanya tercantum dalam suatu himpunan buku-buku yang biasanya juga dianggap sebagai kesusastraan suci. Sistem upacara keagaman menurut (Koentjaraningrat 2015;296) secara khusus mengandung emosi aspek yang menjadi perhatian khusus dari para ahliantroplogi ialah:

1) Tempat upacara keagamaan dilakukan; 2) Saat-saat upacara keagamaan dijalankan; 3) Benda-benda dan alat-alat upacara; 4) Orang-orang yang melakukan dan memimpin upacara.

Aspek yang pertama berhubungan dengan tempat-tempat keramat di mana upacara dilakukan, yaitu makam, candi, pura, kuil, gereja, langgar, surau, mesjid dan sebagainya. Aspek ke-2 adalah aspek yang mengenai saat-saat beribadah, hari-hari keramat dan suci dan sebagainya. Aspek ke-3 adalah tentang benda-benda yang dipakai dalam upacara termasuk patung-patung yang melambangkan dewa-dewa, alat-alat bunyibunyian seperti lonceng suci, seruling 
suci, gendering suci dan sebagainya. Aspek ke-4 adalah aspek yang mengani para pelaku upacara keagamaan, yaitu pendeta biksu, syaman, dukun dan lainlain.Menurut upacara itu sendiri banyak juga unsurnya, yaitu: 1) Bersaji, 2) Berkorban; 3) Berdo'a; 4) Makan bersama makanan yang telah disucikan dengan do'a; 5) Menari tarian suci; 6) Menyanyi nyanyian suci; 7)Berpropesi atau berpawai; 8) Memainkan seni darama suci; 9) Berpuasa; 10) Bertapa; 11) Bersemedi. (Hermanto;2012)

Diantara unsur-unsur upacara keagamaan tersebut ada yang dianggap penting sekali dalam satu agama, tetapi tidak dikenal dalam agama lain, dan demikian juga sebaliknya. Selain itu suatu upacara biasanya mengandung suatu rangkaian yang terdiri dari sejumlah unsur tersebut. Dengan demikian dalam suatu upacara untuk kesuburan tanah misalnya, para pelaku upacara dan para pemimpin ritual berpawai terlebih dahulu menuju ke tempattempat bersaji, lalu mengorbankan seekor ayam, setelah itu menyajikan bunga kepada dewa kesuburan, disusul dengan doa yang diucapkan oleh para pelaku, kemudian menyanyi bersama berbagai nyanyian suci, dan akhirnya semuanya bersama kenduri makan hidangan yang telah disucikan dengan do'a.

Ritual dan sistem kepercayaan merupakan salah satu unsur kebudayaan yang bisa dihampiri dalam setiap kelompok masyarakat di dunia. Ritual keagamaan merupakan sarana yang menghubungkan manusia dengan yang keramat, inilah agama dalam praktek (in action). Ritual bukan hanya sarana yang memperkuat ikatan sosial kelompok dan mengurangi ketegangan, tetapi juga suatu cara untuk merayakan peristiwa-peristiwa penting, dan yang menyebabkan krisis seperti kematian, tidak begitu mengganggu bagi masyarakat, dan bagi orangorang yang bersangkutan lebih ringan untuk diderita . ( Soekadijo; 2000)

Upacara sepanjang masa kehidupan masa kehidupan (rites de passage) dilaksanakan oleh setiap masyarakat suku bangsa di dunia, karena upacara ini merupakan upacara rangkaian hidup yang penting bagi kehidupan seorang individu sebagai anggota masyarakat. Hal ini sesuai dengan anggapan Van Gennep yang menyatakan bahwa rangkaian ritus dan upacara sepanjang tahap-tahap pertumbuhan, atau "Lingkaran Hidup" individu (life cycle rites) itu, sebagai rangkaian ritus dalam masyarakat dan kebudayaan manusia. Dengan demikian, upacara lingkaran hidup ini bersifat universal, dimana upacara ini ada pada semua kebudayaan di muka bumi.Oleh karena itu upacara yang dilaksanakan oleh sekelompok masyarakat merupakan perwujudan dari tingkah laku atau tindakan masyarakat tersebut dalam upayanya untuk mendekatkan diri dengan Tuhan-nya.

Dengan demikian, tradisi keagamaan sudah merupakan kerangka acuan norma dalam kehidupan dan perilaku masyarakat dan tradisi keagamaan sebagai pranata primer dari kebudayaan memang sulit berubah, karena keberadaannya didukung oleh kesadaran bahwa pranata tersebut menyangkut kehormatan, harga diri, dan jati diri masyarakat pendukungnya.

Sara, Nagara dan Mokaha adalah falsafah hidup nu di jadi ayah hirup sangkan bisa manusa hurip, Saraadalah Nyanghulu ka hukum (berpegang pada aturan), nagara artinya Nunjang ka Nagara (taat pada negara) dan mokaha artinya mufakat jeung balerea (hidup bersama). Makna kontekstualitasnya adalah bahwa setiap Kasepuhan di Kesatuan Adat Banten Kidul harus senantiasa taat pada aturan 
hukum, baik itu hukum adat maupun hukum pemerintah, lalu harus selalu hidup bersama dan menjaga tali silaturahim serta gotong royong.

Selanjutnya dalam upaya mencapai ketertiban dan keselarasan hidup manusia, warga Kasepuhan harus menyelaraskan ucapan, tingkah laku dan tekad (ucap lampah kalawan tekad). Bagi warga Kasepuhan pedoman hidup berupa tatali paranti karuhun harus dilaksanakan karena setiap pelanggaran terhadapnya akan mengakibatkan bencana (kabendon), baik bagi dirinya maupun masyarakat. Dengan cara itu, maka warga kasepuhan berharap dapat terhindar dari berbagai malapetaka.

Kepercayaan terhadap tatali paranti karuhun terekspresikan dalam berbagai simbol berupa tabu (pantangan). Sebagai contoh adalah : (1) Tabu untuk menjual beras, Ada istilah kasepuhan mupusti pare, lain migusti artinya memuliakan padi tapi bukan menuhankan. Peraturan adat melarang untuk menjual beras sebagai makanan pokok, juga hasil olahan dari beras juga dilarang untuk dijual, akan tetapi masyarakat diijinkan menjual padi apabila ada kelebihan cadangan. (2). Tabu mengeluarkan padi pada hari lahir (wedal), Kemuliaan padi tidak boleh disamakan dengan hari lahir warga kasepuhan. (3) Tabu untuk bersiul di sekitar kampung, Menghindari kesialan bagi diri dan masyarakat sekitar. (4) Tabu untuk mengolah sawah pada hari Jum'at dan Minggu.

Kepercayaan warga Kasepuhan yang tidak boleh diabaikan begitu saja adalah penghormatan kepada Dewi Sri yang dipercayai sebagai "Dewi Padi". Misalnya pandangan terhadap Dewi Sri yang mereka sebut Nyi Pohaci Sanghyang Sri Ratna Inten Purnama Alam Sajati; Dewi Sri hanya bersemayan pada padi sekali dalam setahun, sehingga menyebabkan penanaman padi harus dilakukan sekali dalam setahun. Menurut mereka, berbagai pelanggaran terhadap padi dan tata cara dalam pemeliharaannya, akan menimbulkan ketidakberhasilan panen (tidak sesuai dengan yang diharapkan). Oleh karena itu mudah dimengerti apabila setiap siklus pertanian tidak lepas dari berbagai upacara, misalnya: upacara sasarap, ngabersihan, ngaseuk, tebar, mipit, ngadiukeun, nganyaran, ponggokan, dan seren taun. Demikian pula dalam segi teknologi pertanian pun lebih banyak menggunakan alat-alat tradisional seperti : etem (aniani), lesung, dan rengkong (alat pemikul yang berfungsi untuk membawa pocongan padi dari lantayan ke leuit). Berikut adalah sistem kepercayaan dan kegiatan-kegiatan ritual yang dilaksakanan di Kasepuhankasepuhan Kesatuan Adat Banten Kidul :

(1). Ritual Opat Belasan. Ritual yang dilakukan setiap tanggal 13 malam 14 dalam kalender Islam/ Bulan Saka atau saat bulan purnama muncul. Ritual ini dilaksanakan pada pukul 12 malam sebagai selamatan bulanan. Ritual upacara Opat Belasan ini dihadiri oleh Penghulu yang memimpin doa dan disaksikan oleh para Kolot Lembur. Dalam acara ini diawali dengan ritual berdoa dan hadiah kepada para leluhur lalu setelah selesai berdoa mereka menyantap hidangan antara lain kue-kue seperti apem, cuhcur, sangu ketan 2 congcot, gula sebelah gandu, panyepahan dina bokor, cau omas,papais, awug dan pasungyang telah dibuat oleh ibu-ibu. Pada malam harinya sebelum selamatan dimulai pada pukul 12 malam, ibu-iu membuat rurujakansembilan rupa diantaranya cau emas, anggur, jeruk, nanas, tomat, kelapa, papaya, buah asam dan curing.

(2). Prosesi Sistem Pertanian Sawah dan Ladang (huma) di Kasepuhan Kesatuan Adat Banten Kidul: (a) Ngalantayakeun: Nama Kegiatan Ngabaladah (menyiangi ladang), Waktu Pelasaksanaan Silih Mulud/ Rabiul Akhir. (b) 
Disalametan Nganyaran (selamatan sebagai tanda syukur memasak padi pertama kali) Silih Mulud/ Rabiul Akhir. (c). Ngambangkeun (mengisi lahan dengan air/ merendam) Jumadil Awal. (c) Narawas (menandai lokasi yang akan dijadikan lahan huma) Jumadil Awal. (d) Nyacar (membersihkan lahan, biasanya selama 1 minggu) Jumadil Awal. (e)Tebar/ ngipuk (membuat persemaian padi dengan cara menebar untaian padi) Jumadil Akhir. (f) Ngahuru (membakar semak kering untuk dijadikan pupuk) Jumadil Akhir. (g) Ngerukan (mengumpulkan sisa-sisa yang belum terbakar) Jumadil Akhir (h) Ngaduruk (membakar sisa-sianya) Jumadil Akhir. (i) Nyara (meremahkan tanah) Jumadil Akhir. (j) Ngaseuk (penanaman bibit padi dengan menggunakan tongkat atau aseuk) Rajab (k) Ngangler ( membersihkan lahan dari gulma untuk persiapan tebar) Ruwah/ Syaban 13. Tandur (menanam padi) Ruwah/ Syaban. (1) Ngored (menyiangi rumput) Ruwah/ Syaban. (m) Ngarambet (membersihkan gulma yang ada di sawah) Puasa/ Ramadlan.

(3) Aturan-aturan dan ritual upacara adat yang berkaitan dengan padi : (a) Ngaseuk :prosesi menanam padi dengan dimulainya kegiatan menanam padi dengan memasukkan benih ke dalam lubang aseuk. Prosesi selamatan diawali dengan berziarah ke pemakaman leluhur, lalu menikmati hidangan nasi kebuli yang sudah disiapkan dan menampilkan hiburan kesenian seperti : wayang golek, jipeng, topeng dan pantun buhun. (b) Ritual Sapangjadian Pare sepiritual memohon ijin kepada sang ibu untuk ditanami padi dan meminta restu dari leluhur dan Sang Pencipta agar padi tumbuh dengan baik, syukuran ini dilaksanakan satu minggu setelah tumbuhnya penanaman padi dengan menyajikan bubur sumsum. (c) Sawenan : upacara setelah padi keluar, memberikan pengobatan padi dengan tujuan agar padi selamat dan terisi baik dan terhindar dari hama. (d) Beberes Mager : ritual untuk menjaga padi dari serangan hama. Kegiatan ini dilakukan oleh pemburu di ladang Abah (ladang milik kasepuhan) dengan membaca doa, kegiatan ini dilakukan pada bulan Muharram. (e) Ngarawunan : ritual meminta isi padi agar tumbuh dengan subur, sempurna dan tidak ada gangguan. Kegiatan ini dilakukan oleh semua incu putu (warga kasepuhan) untuk meminta doa ke oleh bagian pamakayaan, ngarawunan dilaksanakan setelah padi berumur sekitar tiga sampai empat bulan. (f) Mipit : kegiatan memanen padi yang dilakukan terlebih dahulu oleh Abah sebagai pertanda masuknya musim panen. (g) Nutu : kegiatan menumbuk padi pertama hasil panen yang dilakukan oleh ibu-ibu sambil bernyanyi "pribumi-pribumi menta kejo dingejoan hulu bogo, hulu bogo geus bilatungan" (h) Nganyaran :ritual saat padi ditumbuk dan dimasak pertama kaliatas hasil panen, biasanya dilaksanakan dua bulan setelah masa panen. (i) Tutup Nyambut : kegiatan akhir dalam hal pertanian yang menandakan selesainya semua aktivitas pertanian di sawah yang ditandai dengan acara salametan. (j) Turun Nyambut : kegiatan pertanian setelah pelaksanaan upacara Seren Taun, kegiatan Turun Nyambut merupakan pertanda dimulainya masa untuk membajak sawah dan mempersiapkan lahan untuk ditanami kembali.

(4) Ritual kepercayaan lain : (a) Sedekah Mulud : adalah prosesi selametan diawali membaca doa namun sajian makanan tidak seperti ritual Opat Belasan, yang disajikan adalah nasi dan lainnya, dalam sidekah mulud para ibu mlai memasak nasi untuk dibawa ke penghulu untuk salametan/ dibacakan doa lalu dibagikan ke warga, sidekah Mulud dilaksanakan pada hari Jumat setelah tanggal 14 bulan Mulud/ Rabiul Awwal. (b) Sedekah Ruwah : adalah ritual peringatan 
wafatnya Nabi Muhammad Saw, kegiatan ini pelaksanaannya hamper sama dengan kegiatan Sedekah Mulud, namun dilaksanakan pada hari Jumat. (c) Prahprahan : merupakan salah satu kegiatan menjaga dan menghindarkan segala penyakit (tolak bala) yang dilakukan pada bulan Safar dalam kalender Islam. Semua warga dan incu putu ditandai oleh ketupat dan tangtang angin baik di rumah maupun di kandang ternak. (d) Nyimur : merupakan kegiatan ritual dimana seluruh balita (usia 0-5 tahun) dikumpulkan untk diteteskan (peureuh) air kembang ke dalam mata. Kegiatan ini dilaksanakan di rumah dukun pada bulan Silih Mulud/ Rabiul Tsani. (e)Beberes Bengkong :salah satu kegiatan setelah mengkhitan semua incu putu baik laki-laki maupun perempuan. Untuk perempuan sekitar 2 atau 3 tahun sedangkan untuk laki-laki sekitar usia 5 sampai 7 tahun. Setelah selesai khitan, yang punya hajat memberikan beras dan uang ke bengkong sebagai parawanten. Kemudian Bengkong (orang yang mengkhitan laki-laki) dan Ema Beurang (yang mengkhitan perempuan) membuat nasi tumpeng yang akan diserahkan ke Abah. (f) Ritual Ronggokan : Seminggu sebelum pelaksanaan Seren Taun, baris kolot berkumpul untuk membahas jumlah jiwa dihitung berdasarkan pajak per jiwa $=$ Rp. 100,- Rumah $=$ Rp. 250,- Motor $=$ Rp. 5000,Mobil Rp. 25.000,-. Kemudian menyerahkan biaya Seren Taun yang telah disepakati sebelumnya dan membahas biaya Seren Taun yang akan datang.

(5) Seren Taun Adalah puncak tradisi dari seluruh rangkaian kegiatan pertanian yang dilaksanakan setiap tahun. Upacara besar dalam menghormati leluhur dan Dewa Sri dengan segala bentuk ritual dan pertunjukkan seni budaya warga kasepuhan dari kesenian yang sangat buhun (lama) sampai dengan kesenian modern ditampilkan untuk masyarakat. Padi dibawa, diarak dan diiringi oleh semua orang, untuk kemudian disimpan di lumbung komunal Leuit Si Jimat. Istilah Seren taun berasal dari kata dalam Bahasa Sunda seren yang artinya serah, seserahan, atau menyerahkan, dan taun yang berarti tahun. Jadi Seren taun bermakna serah terima tahun yang lalu ke tahun yang akan datang sebagai penggantinya. Dalam konteks kehidupan tradisi masyarakat peladang Sunda, seren taun merupakan sarana untuk bersyukur kepada Tuhan Yang Maha Esa atas segala hasil pertanian yang dilaksanakan pada tahun ini, seraya berharap hasil pertanian mereka akan meningkat pada tahun yang akan datang.

\section{KESIMPULAN}

Masyarakat Kesatuan Adat Banten Kidul merupakan masyarakat adat yang masih teguh memegang dan menjalankan tradisi dengan pengawasan Abah sebagai ketua adat. warga kasepuhan merupakan pemeluk agama Islam yang taat, akan tetapi dalam kehidupan sehari-harinya diwarnai oleh kepercayaan-kepercayaan bersifat mitos dan animisme, mereka masih mempertahankan kepercayaaan leluhur seperti membakar menyan, memberikan sesajen, upacara-upacara adat, memasang tolak bala di pintu, dan kepercayaan leluhur lainnya (tatali paranti karuhun). Hal tersebut dapat terlihat dari kehidupan mesyarakatya sehari-hari dalam memegang tradisi adat (tetekon) terutama dalam hal bercocok tanam yang tidak lepas dari aturan (tetekon) yang telah ditentukan oleh pemangku adat. Warga Kasepuhan mempunyai keyakinan bahwa seseorang yang ingin sukses hidupnya atau bahagia, ia harus dapat mencapai satu kesatuan hidup atau rasa manunggal, yakni menyatukan alam makro kosmos dengan mikro kosmos. 
Sebuah ungkapan yang sering dijadikan pedoman untuk mencapai rasa yang dimaksud adalah tilu sapamilu, dua sakarupa, hiji eta keneh (tiga sejenis, dua serupa, satu itu-itu juga). Tata nilai ini mengandung pengertian bahwa hanya dapat dilakukan dengan tiga syarat, yaitu (1) tekad, ucap dan lampah (niat, pemikiran dan tindakan) harus selaras dan dapat dipertanggungjawabkan kepada incu-putu (keturunan masyarakat kasepuhan) dan sesepuh (orang tua dan nenek moyang). 2) jiwa, raga dan perilaku harus selaras dan berakhlak. 3) kepercayaan adat sara, nagara dan mokaha harus selaras, harmonis dan tidak bertentangan satu dengan lainnya. Sara, Nagara dan Mokaha adalah falsafah hidup nu di jadi ayah hirup sangkan bisa manusa hurip, Sara adalah Nyanghulu ka hukum (berpegang pada aturan), nagara artinya Nunjang ka Nagara (taat pada negara) dan mokaha artinya mufakat jeung balerea (hidup bersama). Kepercayaan terhadap tatali paranti karuhun terekspresikan dalam berbagai simbol berupa tabu (pantangan).

Kepercayaan warga Kasepuhan yang tidak boleh diabaikan begitu saja adalah penghormatan kepada Dewi Sri yang dipercayai sebagai “Dewi Padi”. Misalnya pandangan terhadap Dewi Sri yang mereka sebut Nyi Pohaci Sang-hyang Sri Ratna Inten Purnama Alam Sajati; Dewi Sri hanya bersemayan pada padi sekali dalam setahun, sehingga menyebabkan penanaman padi harus dilakukan sekali dalam setahun.

\section{REFERENSI}

Haba, J. (2010). Realitas Masyarakat Adat di Indonesia: Sebuah Refeksi. Jurnal Masyarakat \& Budaya. 12 (2): 255-276.

Hermanto Pasya,G.K. Al Muchtar, S \& Sumaatmadja, N. (2012), Filosof Hidup Sebagai Basis Kearifan Lokal (Studi Pada Masyarakat Banten Kidul), Jurnal Gea; 12(1):1-14.

Koentjaraningrat. (1986). Pengantar Imu Antropologi. jakarta, Aksara Baru. Koentjaraningrat. 1987. Kebudayaan, Mentalitet dan Pembangunan. Penerbit PT. Gramedia.

Kusdiwanggo, S. (2016). Konsep Pola Spasial Permukiman di Kasepuhan Ciptagelar. Jurnal Permukiman. 11(1): 43-56.

Mary Evelyn Tucker dan John A.Grim. (2003). Agama, Filsafat dan Lingkungan Hidup . Kanisius.

Pudjiastuti, SR. (2019). Penelitian Pendidikan. Penerbit Media Akademi.

Pudjiastuti, S.R., Iriansyah H.S., Yuliwati, Y. (2021). "Program Eco-Pesantren Sebagai Model Pendidikan Lingkungan Hidup". Jurnal Abdimas Prakasa Dakara 1(1). 29-37.

Pudjiastuti, S.R. (2020). Etika Lingkungan. Penerbit Gemala.

Piotr Sztompka. (2011). Sosiologi Perubahan Sosial. Prenada. 